\title{
Tissue Inhibitor of Metalloproteinase-1 mRNA is Specifically Induced in Lung Tissue after Birth
}

\author{
PARVIZ MINOO, RAYMOND PENN, DAVID M. DELEMOS, JACQUELINE J. COALSON, AND \\ ROBERT A. DELEMOS \\ Southwest Foundation for Biomedical Research [P.M., R.P., D.M.D.]; the University of Texas Health Science \\ Center [J.J.C.], San Antonio, Texas 78284; and Department of Pediatrics, Women's Hospital, University of \\ Southern California School of Medicine [R.A.D., P.M.], Los Angeles, California 90033
}

\begin{abstract}
Interactions between extracellular matrix, proteins, metalloproteinases, and their inhibitors play a major role in determining the structure of the lung during in utero development and after birth. To better understand the molecular mechanisms underlying lung development and morphogenesis, expression of the tissue inhibitor of metalloproteinases (TIMP-1) gene was examined 1) through the course of late fetal development, 2) when normal fetal development was interrupted by premature birth and extrauterine survival, and 3) during exposure of prematurely delivered neonates to hyperoxia. Total RNA isolated from lung tissue of fetal baboons (Papio sp) at 140,150 , and $180 \mathrm{~d}$ of gestation (term gestation $=180 \mathrm{~d}$ ); baboons prematurely delivered at $140 \mathrm{~d}$ of gestation, 1,2 , 6 , and $10 \mathrm{~d}$ old; and premature baboons ventilated for 6 and $10 \mathrm{~d}$ with $100 \%$ oxygen was examined by Northern blot analysis. The results demonstrated that TIMP-1 mRNA, which is expressed at low levels during fetal development, undergoes a marked increase in abundance shortly after both premature and term birth. This parturition-induced pattern of gene expression appears to be tissue specific to the lung and, contrary to results reported for adult and neonatal animals, is not affected by ventilation of the premature lungs with $100 \%$ inspired oxygen. Although the physiologic consequences of TIMP-1 mRNA induction by birth are not yet known, these data suggest a possible role for TIMP-1 in postnatal adaptation of lung tissue. (Pediatr Res 34: 729-734, 1993)
\end{abstract}

\section{Abbreviations}

ECM, extracellular matrix

$\mathrm{FiO}_{2} 1.0,100 \%$ oxygen

PRN, clinically appropriate

TIMP, tissue inhibitor of metalloproteinases

SSC, standard saline citrate

Mammalian development and morphogenesis is accomplished by spatiotemporally specified patterns of cellular proliferation and differentiation. These processes occur within an architectural framework known as the connective tissue or ECM and are guided by the action of diffusible factors such as cytokines. Collagen fibers are the major constituent of the ECM, and their breakdown is a key step in processes requiring scheduled (devel-

Received May 12, 1993; accepted July 29, 1993.

Correspondence and requests: Parviz Minoo, Ph.D., Department of Pediatrics, University of Southern California School of Medicine, Women's Hospital L-919, 1240 North Mission Rd., Los Angeles, CA 90033.

Supported by Grants HL48298 from the National Institutes of Health and RG109-N from the American Lung Association. opmental) or unscheduled (injury) tissue remodeling. Collagen metabolism is regulated in part by a balance between the activities of two sets of proteins: metalloproteinases such as collagenase, which degrade collagen, and TIMP, which counteracts their activity. TIMP-1 is a glycoprotein member of the metalloproteinase inhibitors that binds to activated interstitial collagenase, activated stromelysin, and type IV collagenase (1-3). Cells that produce interstitial collagenase can also synthesize and secrete TIMP-1. In these cells, the net collagenolytic activity can be modulated by the activated enzyme and TIMP-1 levels (4). The human TIMP-1 gene has been isolated, sequenced, and mapped $(5,6)$.

Morphogenesis of the lung, particularly during early development and perhaps postnatally, is sensitive to the pattern and composition of the $\operatorname{ECM}(7,8)$. Branching morphogenesis of the lung, which is dependent on mesenchymal-epithelial interactions, does not occur in the absence of a functional ECM at the interface of the two interacting tissue layers $(7,8)$. Similarly, postnatal lung development probably occurs on a functional ECM whose structural modification may be necessary for adaptation of the lung from a liquid breathing phase to an air breathing phase at birth. One important role for the ECM is in regulating the growth and differentiation of various cell types. Thus, some components of the ECM, such as certain proteolytic fragments of laminin, have growth factor activity on cultured cells (9). However, a novel mechanism of growth control in tissues may entail the ability of the ECM to regulate the sequestration and timely release of peptide growth factors (e.g. basic fibroblast growth factor) (10). This form of regulation can be mediated by the interplay between the ECM degrading enzymes (e.g. metalloproteinases) and their inhibitors such as TIMP-1. Thus, during tissue morphogenesis and remodeling, levels and/ or activity of proteinases and their inhibitors may be modulated to regulate the release of biologically active cytokines stored in the ECM depot.

We have been interested in the regulatory mechanisms that control in utero and postnatal development of the lung and how they may be altered in pathophysiologic conditions. In this paper, we report studies that examined the expression of TIMP-1, a key regulatory protein involved in ECM turnover, in both fetal and premature baboon lungs. TIMP-1 transcripts have been identified during early embryogenesis in the mouse (11). However, the regulation of this gene during fetal development has not been elucidated nor is it known whether it is influenced by birth. Previous studies have demonstrated increased expression of TIMP-1 mRNA in the lungs of rabbits exposed to hyperoxia (12, 13). It is unclear whether this increase occurs in the lungs of premature infants, who as a consequence of birth itself undergo a 6-fold increase in inspired oxygen tension, and also frequently require supplemental oxygen to sustain life (14).

The present studies were performed in a unique model of fetal development, premature birth, and survival (15). This model 
allows the characterization of genetic programs expressed during normal development and offers information on how these programs may be altered when in utero development is interrupted by premature birth. Our findings demonstrated that TIMP-1 expression in the lung occurs at low levels during fetal development and is increased in a tissue-specific manner in the lungs of term and premature animals upon parturition. Furthermore, in support of our previous studies on regulation of surfactant protein gene expression (16), these data demonstrated that premature infants differ from neonatal or adult animals in many aspects of gene regulation. Functional consequences of these observations are discussed. Preliminary observations of these studies were previously published in abstract form (17).

\section{MATERIALS AND METHODS}

Detailed descriptions of this model have been reported previously $(14,15)$. Briefly, when delivered at $140 \mathrm{~d}$ (of 180-d term gestation), the premature baboon develops hyaline membrane disease that is biochemically, clinically, and morphologically identical with that in human premature infants. Animals supported with positive pressure ventilation and PRN oxygen require high $\mathrm{FiO}_{2}$ and ventilator pressures for the first few days, have onset of recovery late in the second day of life, and do not develop chronic lung disease. However, treatment with positive pressure ventilation and $\mathrm{FiO}_{2} 1.0$ for $10 \mathrm{~d}$ or longer results in a predictable homologue of bronchopulmonary dysplasia with clinical, radiographic, and morphologic findings typical of the human disease.

Gestational ages were determined by matings that were timed by observation of perineal sex skin changes and confirmed by ultrasound examination at intervals during the pregnancy. Fetal animals were delivered by hysterotomy at 140,150 , or $180 \mathrm{~d}$ of gestation and immediately killed, without breathing air, by an overdose of barbiturates. Premature animals were delivered by hysterotomy at $140 \mathrm{~d}$ of gestation, intubated, and resuscitated, and placed on a time-cycled ventilator. Their intensive care management was similar to that used for human premature infants and has been reported previously (14). Premature baboons were maintained on ventilatory support for $24 \mathrm{~h}(140+$ $1 \mathrm{~d}), 48 \mathrm{~h}(140+2 \mathrm{~d}), 144 \mathrm{~h}(140+6 \mathrm{~d})$, or $240 \mathrm{~h}(140+10 \mathrm{~d})$ in either PRN or $100 \%$ oxygen $\left(\mathrm{FiO}_{2} 1.0\right)$ for the duration of the experimental period. In addition, two spontaneously delivered term infant baboons were electively killed by an overdose of anesthesia at $48 \mathrm{~h}$ of age $(180+2 \mathrm{~d})$. At autopsy, a segment of the lung was removed, frozen in liquid nitrogen, and stored at $-80^{\circ} \mathrm{C}$.

Extraction and analysis of RNA. RNA was extracted from frozen lung samples using a modified method of Chirgwin et al. (18). Lung tissues from three animals were examined separately in each case. Approximately $0.5 \mathrm{~g}$ of frozen tissue was ground to a powder in a crucible containing liquid nitrogen. The pulverized tissue was transferred to a tube to which $25 \mathrm{~mL}$ of diethylpyrocarbonate-treated homogenization buffer $(3 \mathrm{M} \mathrm{LiCl}, 10 \mathrm{mM}$ $\mathrm{NaAc}$, pH 5.0, $6 \mathrm{M}$ urea, $0.2 \mathrm{mM}$ vanadyl ribonucleoside complexes) were added. This mixture was homogenized with a motordriven homogenizer, and the homogenate was stored at $-20^{\circ} \mathrm{C}$ overnight to precipitate the RNA. The precipitate was then pelleted by centrifugation, resuspended in guanidinium thiocyanate homogenization buffer ( $4 \mathrm{M}$ guanidinium isothiocyanate, 5 $\mathrm{mM}$ sodium citrate, $\mathrm{pH} 7.0,0.1 \mathrm{M} \beta$-mercaptoethanol, and 0.5 wt/vol Sarkosyl, Sigma, St. Louis, MO), layered over a $5.7 \mathrm{M}$ $\mathrm{CsCl}$ cushion, and centrifuged at $32000 \mathrm{rpm}$ in a Beckman L870 ultracentrifuge using the SW41 Ti rotor at $20^{\circ} \mathrm{C}$ for $18-20 \mathrm{~h}$. Pelleted RNA was subsequently dissolved in $1 \% \mathrm{wt} / \mathrm{vol}$ SDS, 0.5 mM EDTA, extracted with phenol-chloroform, and precipitated with ethanol. The final RNA pellet was collected by centrifugation and redissolved in diethylpyrocarbonate-treated water for further analysis.

For Northern blot analysis, RNA concentrations were deter- mined by spectrophotometry at $260 \mathrm{~nm}$ and equal amounts (approximately $10 \mu \mathrm{g}$ ) of RNA were denatured in a formaldehyde/formamide solution (19), heated at $65^{\circ} \mathrm{C}$ for $5 \mathrm{~min}$, and quenched on melting ice. RNA was resolved by gel electrophoresis on $1.2 \%$ agarose/formaldehyde gels at $50 \mathrm{~V}$ for $2-3 \mathrm{~h}$. Northern blot analysis was performed as described by Thomas (20). The RNA was transferred to Hybond-N (Amersham, Buckinghamshire, UK) membranes overnight, washed the next day in $2 \times \mathrm{SSC}$ for $2 \mathrm{~min}$, and baked at $80^{\circ} \mathrm{C}$ for $2 \mathrm{~h}$ before hybridization.

For quantitative slot-blot analysis, two identical but separate blots of total denatured RNA were prepared as follows. For each sample, 2 and $10 \mu \mathrm{g}$ of total RNA were blotted identically on Nytran filters (Schleicher and Schuell, Keene, NH). After UV cross-linking of the RNA to Nytran (according to manufacturer's specifications), the filters were prehybridized and subsequently hybridized with either TIMP- 1 or the $\beta$-actin probes. Steady state levels of $\beta$-actin were used as a control against which the abundance of TIMP-1 mRNA was quantified among different samples. The integrity of each RNA sample was first confirmed by Northern blot analysis before use on the slot blots. For quantification, various exposures of the autoradiograms were scanned with a densitometer (Ultroscan, XL, Pharmacia LKB, Uppsala, Sweden). Table 1 presents the calculated means \pm SD of the densitometric ratios of autoradiographic signals for TIMP-1/ $\beta$ actin mRNA for each experiment.

Preparation and use of DNA probes. A plasmid containing human TIMP-1 genomic DNA (ATCC 59667) was purchased from the American Type Culture Collection (Rockville, MD). A genomic clone containing the sequences for $\beta$-actin was used to determine the expression of a constitutively expressed gene and to normalize the amounts of RNA on Northern and slot blots. The inserts were subcloned into pGEM 4Z (Promega, Madison, WI) and, after growth and purification of the plasmids, were excised using the appropriate restriction enzymes and subsequently purified by agarose gel electrophoresis and electroelution. The purified inserts were radioactively labeled with $\left[\alpha-{ }^{32} \mathrm{P}\right]$ deoxycytidine 5 '-triphosphate using a random primer labeling technique (21), and the products were purified by two rounds of Sephadex G-50 spin column chromatography. Blots were first prehybridized by incubation in hybridization buffer (19) for $4 \mathrm{~h}$ at $42^{\circ} \mathrm{C}$. Hybridization was then performed at $42^{\circ} \mathrm{C}$ by incubating the blots in hybridization buffer $(5 \times \mathrm{SSC}, 50 \%$ formamide, $5 \times$ Denhardt's) containing $10 \%$ dextran sulfate and the desired ${ }^{32} \mathrm{P}$ labeled probe overnight. The following morning, the blots were washed stringently for $2 \mathrm{~h}$ in $0.1 \times \mathrm{SSC}$ and $0.1 \% \mathrm{SDS}$ at $50^{\circ} \mathrm{C}$ with several changes. Blots were then autoradiographed with $\mathrm{X}$ OMAT AR film (Kodak) at $-70^{\circ} \mathrm{C}$ using Kodak X-Omatic regular intensifying screens. For multiple probing of the same blot, subsequent hybridizations were performed by first removing the previous probe by soaking the blot in near-boiling water for $30 \mathrm{~min}$ and then hybridizing as described above.

Table 1. Measurement of TIMP-1 mRNA during hyperoxia*

\begin{tabular}{|c|c|c|}
\hline Age (d) & $\mathrm{O}_{2}$ treatment & TIMP-1/ $\beta$-actin \\
\hline \multirow{2}{*}{$140+6$} & PRN & $0.609 \pm 0.138$ \\
\hline & $\begin{array}{l}\mathrm{FiO}_{2} 1.0 \\
\mathrm{PRN}\end{array}$ & $0.580 \pm 0.120$ \\
\hline & $\mathrm{FiO}_{2} 1.0$ & $0.623 \pm 0.091$ \\
\hline
\end{tabular}

* Values represent the calculated means \pm SD of the densitometric ratios of autoradiographic signals for TIMP-1/ $\beta$-actin mRNA for each experiment $(n=3)$. Animals were prematurely delivered at $140 \mathrm{~d}$ of gestational age and treated with hyperoxia $\left(\mathrm{FiO}_{2} 1.0\right)$ or normoxia (PRN) for 6 and $10 \mathrm{~d}$, respectively. 


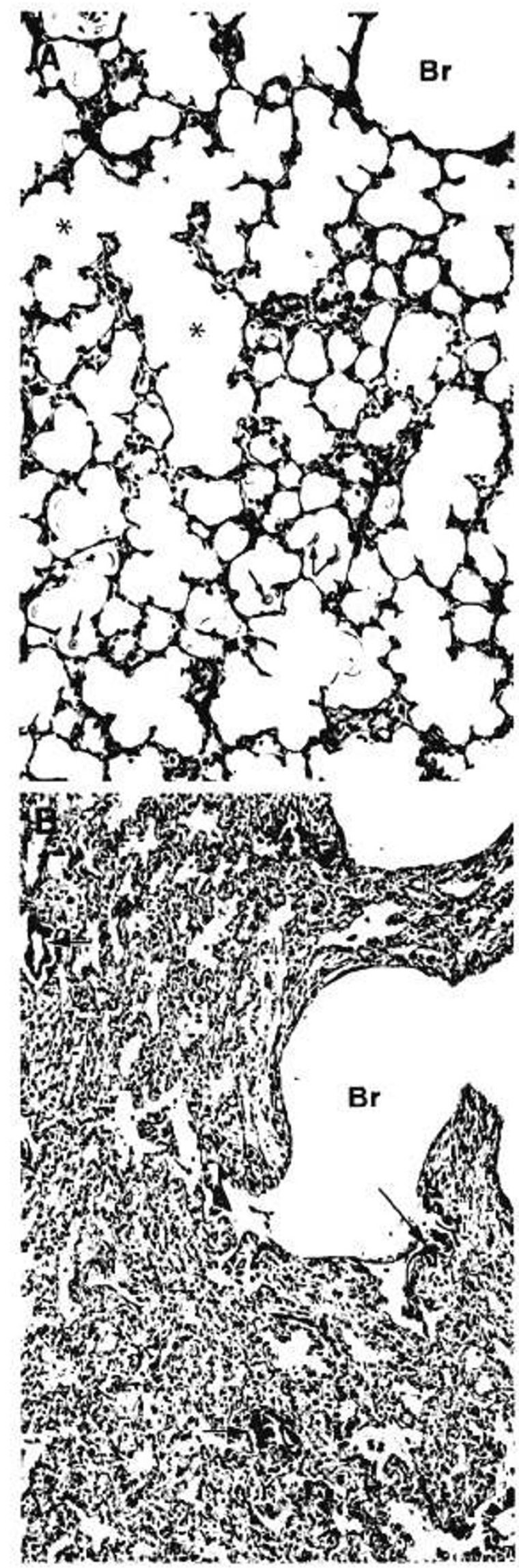

Fig. 1. Histologic findings in the lungs of fetal and premature baboons. $A, 140$-d gestation control. The bronchiole $(B r)$ and several alveolar ducts $\left(^{*}\right)$ are present. The saccules (primitive alveoli) show secondary crest and early alveolar configurations. A few squamous cells

\section{RESULTS}

Treatment of premature baboons. The clinical course of the 1-, 2-, 6- and 10-d-old animals was similar to that previously described from our laboratory $(14,15)$. All the premature baboons developed hyaline membrane disease and required substantial ventilator support. Comparison of histologic findings in the lungs of 140-d baboon fetuses and $140+2 \mathrm{~d}$ premature baboon neonates showed significant lung injury by $2 \mathrm{~d}$ of postnatal life (Fig. 1). In spite of high ventilator pressures (mean pressure 13$14 \mathrm{~cm} \mathrm{H}_{2} \mathrm{O}$ ), the PRN animals required an $\mathrm{FiO}_{2}$ between 1.0 and 0.8 for the first $42 \mathrm{~h}$; then they could be progressively weaned to levels below 0.3 by $96 \mathrm{~h}$ of age. In the hyperoxic animals, $\mathrm{FiO}_{2}$ and $\mathrm{PO}_{2}$ remained elevated throughout the treatment period, although, in contrast to the PRN animals, progressive disease led to a significant fall in arterial/alveolar oxygen after $\mathrm{d} 4$.

Expression of TIMP-I in fetal and postnatal lung tissue. Expression of TIMP-1 through the course of late in utero development and during premature delivery and adaptation to the extrauterine environment was examined by Northern blot analysis of RNA. Total RNA samples, extracted from fetal lung tissues of animals at 140,150, and $180 \mathrm{~d}$ (term) gestational age as well as from prematurely delivered fetuses of $140 \mathrm{~d}$ gestational age who were treated with PRN oxygen for $24 \mathrm{~h}(140+1 \mathrm{~d}), 48 \mathrm{~h}$ $(140+2 d)$, and 6 and $10 d(140+6 d$ and $140+10 d)$, were resolved by gel electrophoresis, transferred to Hybond- $\mathrm{N}$ membranes, and probed with radioactively labeled TIMP-1 genomic DNA insert. Figure 2 shows the results of autoradiography of a representative analysis. TIMP-1 DNA probe was hybridized to an mRNA with an electrophoretic mobility corresponding to approximately $0.9 \mathrm{~kb}$, consistent with the size of the human TIMP-1 mRNA previously reported (22). Although expression of TIMP-1 mRNA in fetal samples was very low, it was nevertheless detectable after long exposure of the blots or overloading of the RNA quantity in specific lanes (see for example Fig. 2, lane A). In contrast, however, a significant increase in TIMP-1 mRNA abundance occurred within $24 \mathrm{~h}$ after birth (Fig. 2, lane $D$ ). Thereafter, TIMP-1 mRNA levels appeared to stabilize and remained stable through $\mathrm{d} 10$, demonstrating that expression of TIMP-1 mRNA in the lung was low during late fetal development and underwent a marked increase within $24 \mathrm{~h}$ after the birth of premature fetuses.

TIMP-I gene expression and prematurity. We next asked whether the increase in TIMP-1 mRNA abundance observed in the previous experiments occurred only as a consequence of premature birth or whether it also occurred during term delivery. To address this question, we compared TIMP-1 mRNA levels among total RNA samples isolated from lung tissues of $180-\mathrm{d}$ fetuses, lung samples of $140+2 \mathrm{~d}$ prematurely delivered infants, and $180+2 \mathrm{~d}$ term delivered infants. Northern blot analysis of these samples revealed that TIMP-1 mRNA was detectable in only the two postnatal samples (Fig. 3). Therefore, expression of TIMP-1 at birth was related to delivery and extrauterine adaptation and was independent of the level of fetal maturation.

Tissue specificity of TIMP-1 mRNA induction after birth. To determine whether parturition-induced accumulation of TIMP1 mRNA occurs in other tissues or specifically in the lung, two other tissues in the prematurely delivered fetuses were examined for the expression of this gene. RNA was isolated from liver and kidneys of prematurely delivered $140-\mathrm{d}$ gestational age animals who were maintained in the extrauterine environment for 0 (control) and $48 \mathrm{~h}$. Northern blot analysis of these samples revealed that TIMP-1 mRNA was specifically induced only in the postnatal lung tissue (Fig. 4, lane B). Therefore, although not

are present in the air spaces (arrows). $B, 140+2 \mathrm{~d}$ premature baboon. The bronchiole $(\mathrm{Br})$ is dilated and partially lined with hyaline membranes (long arrow). The distal air spaces are collapsed and some show hyaline membranes (short arrows). Both specimens were fixed in phosphate-buffered $4 \%$ paraformaldehyde- $0.1 \%$ glutaraldehyde and stained with hematoxylin and eosin $(\times 160)$. 


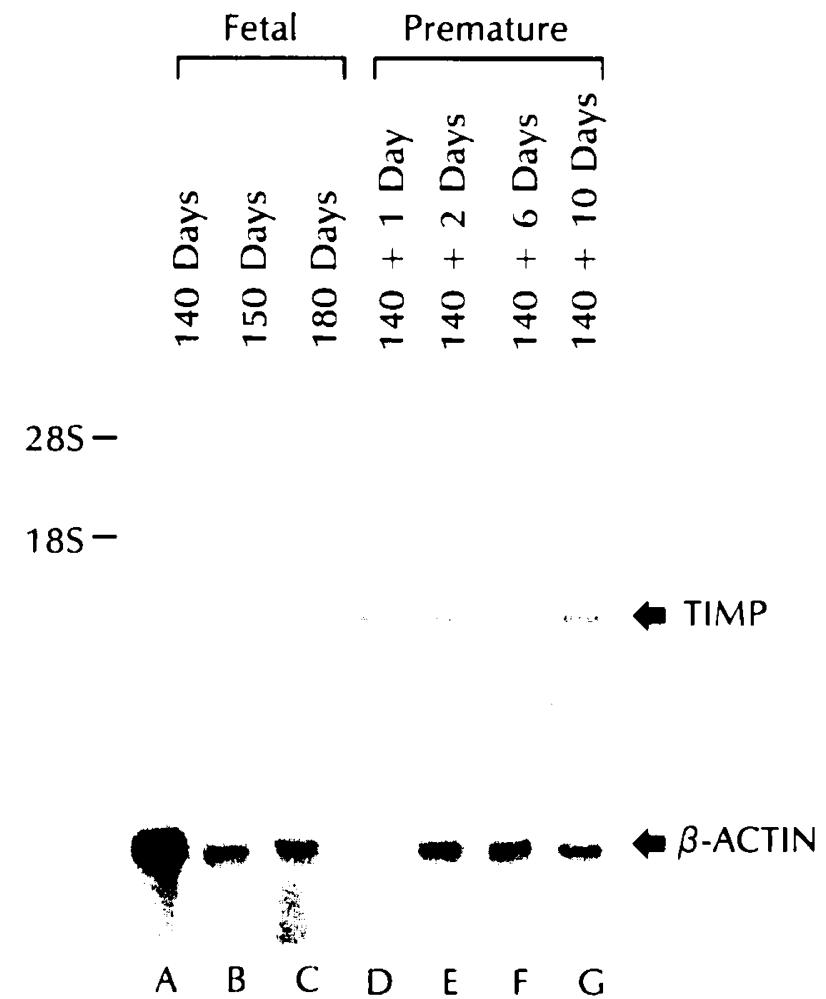

Fig. 2. A representative Northern blot of TIMP-1 mRNA abundance in fetal and postnatal lung tissue. With the exception of lane A, approximately equal quantities $(10 \mu \mathrm{g})$ of total RNA isolated from lung of fetal and prematurely delivered baboons were resolved by electrophoresis on $1.2 \%$ formaldehyde agarose gels and blotted onto Hybond- $\mathrm{N}$, as described in Materials and Methods. The amount of RNA in lane A was intentionally overloaded $(5 x)$ to demonstrate TIMP- $1 \mathrm{mRNA}$ in fetal samples. The filter was hybridized with a TIMP-1 ${ }^{32} \mathrm{P}$-labeled DNA probe prepared by the random primer labeling method and autoradiographed. Lower panel, the same blot probed with a ${ }^{32} \mathrm{P}$-labeled $\beta$-actin genomic clone.

an exhaustive tissue survey, these experiments clearly demonstrated that accumulation of TIMP-1 mRNA within $48 \mathrm{~h}$ after birth was tissue specific.

Effect of hyperoxia on postnatal levels of TIMP-I MRNA in prematurely delivered infants. Exposure to hyperoxic levels of inspired oxygen for 64-96 h increases TIMP-1 and surfactantassociated protein A mRNA levels in the lungs (12). The increase in TIMP-1 mRNA has been speculated to be an early marker of pulmonary fibrosis. In contrast to these studies, we have recently shown that the increase in surfactant-associated protein $A$ mRNA level in response to hyperoxia does not occur in prematurely delivered baboons (16). To determine the effect of hyperoxic exposure and/or lung injury on regulation of TIMP-1 gene expression in the premature infants, the abundance of TIMP-1 mRNA was determined by quantitative slot-blot analysis. These analyses demonstrated that the abundance of mRNA for TIMP-1 does not change significantly between premature baboons ventilated with $100 \%$ oxygen for 6 and $10 \mathrm{~d}$ and those ventilated with PRN oxygen (Table 1), even though, as described previously $(14,15)$, animals exposed to $10 \mathrm{~d}$ of hyperoxia have significant lung injury. Therefore, postnatal levels of TIMP-1 mRNA in prematurely delivered baboons were not increased by hyperoxic lung injury.

\section{DISCUSSION}

In the present study, we have examined the effect of in utero development, premature birth and survival, and postnatal exposure to hyperoxia on TIMP-1 mRNA abundance in the im-

\section{Gestational Age}

\section{a $\beta$ - ACTIN \\ A B C}

Fig. 3. Postnatal increase in TIMP-1 mRNA. The abundance of TIMP-1 mRNA in $10 \mu \mathrm{g}$ of total RNA from the lung tissue of 180-d fetuses, $140+2 \mathrm{~d}$ premature neonates, and $180+2 \mathrm{~d}$ term neonates was examined by Northern blot analysis; upper panel, probed with TIMP$1{ }^{32} \mathrm{P}$-labeled DNA; lower panel, the same filter probed with a ${ }^{32} \mathrm{P}$-labeled $\beta$-actin genomic clone.

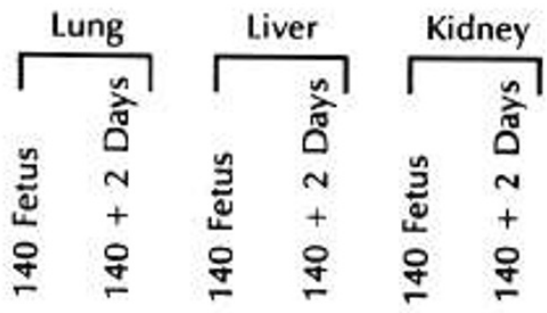

$28 \mathrm{~S}$

$18 \mathrm{~S}$

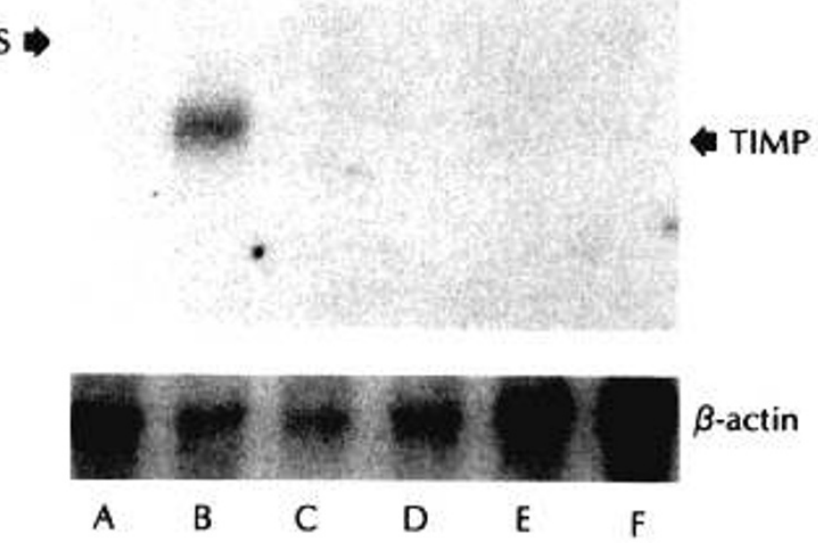

Fig. 4. Tissue-specific expression of TIMP-1 mRNA. Total RNA from liver, kidney, and lung tissues of $140-\mathrm{d}$ fetal and $140+2 \mathrm{~d}$ postnatal baboons was analyzed on a Northern blot. The blot was probed with ${ }^{32} \mathrm{P}$ labeled TIMP-1 DNA (upper panel) and a $\beta$-actin genomic probe (lower panel) and autoradiographed. 
mature baboon lung. Our findings demonstrated that I) mRNA for TIMP-1 was expressed at low levels during late fetal development, 2) delivery and oxygen breathing in term or premature fetuses was associated with a marked increase in TIMP-1 mRNA abundance, 3 ) this parturition-induced gene expression was regulated in a tissue-specific manner, and 4) postnatal levels of TIMP-1 mRNA were not increased by lung injury from ventilation of the premature baboon lung with $100 \%$ oxygen.

TIMP-1 is an inhibitor of a variety of metalloproteinases including collagenase, gelatinase, stromelysin, and proteoglycanase (1, 23-26). TIMP-1 is produced and secreted by human fibroblasts, smooth muscle cells, osteoblasts, and human mononuclear phagocytes $(1,27)$. Based on its prevalence and ability to bind degradative enzymes with high affinity, TIMP-1 is believed to be a key regulator of ECM turnover $(1,23-26)$. Brenner et al. (11) have recently identified TIMP-1 transcripts in mouse embryos, suggesting a role for TIMP-1 in ECM remodeling during early embryogenesis. TIMP-1 mRNA levels during later stages of development have not been previously examined.

Our results revealed the presence of very low levels of TIMP1 mRNA in fetal baboon lung at 140,150, and $180 \mathrm{~d}$ of gestation (lanes $A-C$, Fig. 2). The abundance of TIMP-1 mRNA did not change significantly during this developmental window. However, both term and premature delivery (at $140 \mathrm{~d}$ of gestation) followed by air breathing and extrauterine adaptation induced a marked increase in TIMP-1 mRNA levels (Fig. 2). It is noteworthy that the increase during the $48 \mathrm{~h}$ of postnatal development occurred with tissue specificity in that at least liver and kidney samples from the same animals did not exhibit increased TIMP-1 mRNA levels after birth. For the majority of genes examined to date, increased mRNA abundance results in increased protein synthesis. Where it has been studied, increased TIMP 1 mRNA is accompanied by a concomitant increase in TIMP-1 protein (28). However, we do not know whether the increase in TIMP-1 mRNA described here leads to increased TIMP-1 protein levels. We are currently developing specific antiTIMP-1 MAb to address this issue. In future experiments, it will also be necessary to determine the specific cells involved in parturition-induced TIMP-1 gene expression. Fibroblasts and macrophages $(1,27)$, as well as chondrocytes of the cartilage surrounding airways and pulmonary endothelial cells (29), have been known to express TIMP-1 mRNA. In the present study, the relative paucity of fibroblasts and macrophages in the premature baboon lung at $24 \mathrm{~h}(30)$, coupled with the rapid increase in abundance of TIMP-1 mRNA, makes it unlikely that the observed increase is the result of cell proliferation in these two cell populations. We have previously shown that premature baboons treated with positive pressure ventilation and prolonged hyperoxia develop bronchopulmonary dysplasia with increased fibrosis (15). This observation, coupled with the findings in adult and term neonatal rabbits $(12,13)$ raised the possibility that exposure to hyperoxia might also increase TIMP-1 mRNA levels in the premature baboon lung. However, we found no differences in postnatal abundance of TIMP-1 mRNA between hyperoxic and normoxic animals on $\mathrm{d} 6$ or 10 . The fact that our results differ from those of previous studies $(12,13)$ might be explained by differences in animal species, maturity, and physiology. The inflammatory response to hyperoxia in the 140-d-gestation premature baboon lung is much less severe than that observed in older animals $(14,15,30)$. Because mononuclear phagocytes produce TIMP-1 and fibroblast production of TIMP-1 is influenced by factors produced by inflammatory cells $(28,31)$, differences in the magnitude of the inflammatory response may account for maturation-related differences in TIMP-1 gene expression occurring secondarily to hyperoxia. Exposure of term neonatal baboons to hyperoxia was not examined in the present study.

The specific effectors of the observed increase in TIMP-1 mRNA are unknown. In cultured fibroblasts, retinoic acid (28), as well as growth factors in the presence of transforming growth factor- $\beta$ (31), is known to increase both TIMP-1 mRNA and protein. Preliminary studies using the polymerase chain reaction have demonstrated that both platelet-derived growth factor and transforming growth factor- $\beta$ mRNA are expressed in the developmental window described in the present studies (32). Changes in the expression of these and other cytokines may mediate alterations in gene expression (e.g. TIMP-1) associated with development and parturition.

Because an increase in the level of TIMP-1 mRNA was found after both premature and term birth, we compared some of the pulmonary and nonpulmonary factors known to be associated with each of these situations. Both term and premature births result in a significant increase in alveolar oxygen tension. Similarly, significant elevation in circulating catecholamines occurs in both cases $(33,34)$. Unlike the term infant, however, the 140-d premature baboon has substantial oxygen requirement, develops hyaline membrane disease, and has significant lung injury by $24 \mathrm{~h}(8,10)$. Because a birth-related hyperoxic challenge is common to both premature and term infants, one hypothesis derived from these data suggests that changes in lung cellular oxygen tension mediate the birth-related induction of TIMP-1 gene expression. Such a mechanism, if present, would have to be independent of oxidant injury (at least in the premature baboon), inasmuch as both term and premature birth result in a significant induction of TIMP-1 mRNA. In this light, lack of TIMP-1 responsiveness to prolonged hyperoxic exposure in premature infants $(140+6 \mathrm{~d}$ and $140+10 \mathrm{~d})$ is not presently understood. However, among many plausible explanations, it is possible that either the TIMP-1 gene is maximally expressed in this developmental window or there are developmental differences in response mechanisms to hyperoxia between immediate postnatal and more developed infants. Furthermore, although we found no net change in the steady state levels of TIMP-1 mRNA between normoxic and hyperoxic premature baboons, we cannot rule out the possibility of other changes such as shifts in the cellular site of TIMP-1 mRNA expression. In future experiments, in situ localization of TIMP-1 mRNA in lung tissue may provide the necessary information to ascertain this possibility.

Acknowledgment. The authors thank the staff of the Technical Publications Department of Southwest Foundation for Biomedical Research for preparation of the manuscript.

\section{REFERENCES}

1. Welgus HG, Stricklin GP 1983 Human fibroblast collagenase inhibitor: comparative studies in human connective tissues, serum and amniotic fluid. $J$ Biol Chem 258:12259-12264

2. Welgus HG, Jeffrey JJ, Eisen AZ, Roswit WT, Stricklin GP 1985 Human skin fibroblast collagenase: interaction with substrate and inhibitor. Collagen Relat Res 5:167-179

3. Wilhelm SM, Collier IE, Marmer BL, Eisen AZ, Grant GA, Goldberg GI 1989 SV40-transformed human lung fibroblasts secrete a 92-kDa type IV collagenase which is identical to that secreted by normal human macrophages. J Biol Chem 264:17213-17221

4. Herron GS, Banda MJ, Clark EJ, Gavrilovic J, Werb Z 1986 Secretion of metalloproteinases by stimulated capillary endothelial cells. II. Expression of collagenase and stromelysin activities is regulated by endogenous inhibitors. J Biol Chem 261:2814-2818

5. Carmichael DF, Sommer A, Thompson RC, Anderson DC, Smith CG, Welgus HG, Stricklin GP 1986 Primary structure and cDNA cloning of human fibroblast collagenase inhibitor. Proc Natl Acad Sci USA 83:2407-2411

6. Mahtani MM, Willard HF 1988 A primary genetic map of the pericentromeric region of the human X chromosome. Genomics 2:294-301

7. Adamson IYR 1991 Development of lung structure. In: Crystal RG, West JB, Barnes PJ, Cherniack HS, Weibel, ER (eds) The Lung: Scientific Foundations. Raven Press, New York, pp 663-670

8. Wessels NK, Cohen JA 1968 Effects of collagenase on developing epithelia in vitro: lung, uretic bud and pancreas. Dev Biol 18:294-309

9. Schuger L, Skubitz APN, O'Shea KS, Chang JF, Varani J 1991 Identification of laminin domains involved in branching morphogenesis: effects of antilaminin monoclonal antibodies on mouse embryonic lung development. Dev Biol 146:53!-54!

10. Vlodavsky I, Bar-Shavit Z, Ishai-Michaeli R, Bashkin P, Fuks Z 1991 Extracellular sequestration and release of fibroblast growth factor: a regulatory mechanism? Trends Biochem 268-271 
11. Brenner CA, Adler RR, Rappolee DA, Pederson RA, Werb Z 1989 Genes for extracellular matrix-degrading metalloproteinases and their inhibitor, TIMP1, are expressed during early mammalian development. Genes Dev 3:848859

12. Horowitz S, Dafni N, Shapiro DL, Holm BH, Notter RH, Quible DJ 1989 Hyperoxic exposure alters gene expression in the lung: induction of the tissue inhibitor of metalloproteinases mRNA and other mRNAs. J Biol Chem 264:7092-7095

13. Horowitz S, Shapiro DL, Finkelstein JN, Notter RH, Johnston CJ, Quible DJ 1990 Changes in gene expression in hyperoxia-induced neonatal lung injury. Am J Physiol 258:L107-L111

14. deLemos RA, Coalson JJ, Gerstmann DR, Kuehl TJ, Null Jr DM 1987 Oxygen toxicity in the premature baboon with hyaline membrane disease. Am Rev Respir Dis 136:677-682

15. Escobedo MB, Hilliard JL, Smith F, Meredith K, Walsh W, Johnson D, Coalson JJ, Kuehl TJ, Null Jr DM, Robotham JL 1982 A baboon model of bronchopulmonary dysplasia. I. Clinical features. Exp Mol Pathol 37:323334

16. Minoo P, Segura L, Coatson JJ, King R, deLemos R 1991 Alterations in surfactant protein gene expression associated with premature birth and exposure to hyperoxia. Am J Physiol 261:L386-L392

17. Minoo P, Penn R, Garcia P, Segura L, deLemos RA 1991 Developmental regulation of tissue inhibitor of metalloproteinases (TIMP-1) mRNA in the lung. Am Rev Resp Dis 143:A502(abstr)

18. Chirgwin JM, Przybyla AE, MacDonald RJ, Rutter WJ 1979 Isolation of biologically active ribonucleic acid from sources enriched in ribonuclease. Biochemistry 18:5294-5299

19. Maniatis T, Fritsch EF, Sambrook J 1982 Molecular Cloning: A Laboratory Manual. Cold Spring Harbor Laboratory, New York

20. Thomas PS 1980 Hybridization of denatured RNA and small DNA fragments transferred to nitrocellulose. Proc Natl Acad Sci USA 77:5201-5205

21. Feinberg AP, Vogelstein B 1983 A technique for radiolabeling DNA restriction endonuclease fragments to high specific activity. Anal Biochem 132:6-13

22. Gasson JC, Golde DW, Kaufman SE, Westbrook CA, Hewick RM, Kaufman RJ, Wong GG, Temple PA, Leary AC, Brown EL, Orr EC. Clark SC 1985 Molecular characterization and expression of the gene encoding human erythroid-potentiating activity. Nature 315:768-771
23. Gavrilovic JRM, Hembry RM, Reynolds JJ, Murphy G 1987 Tissue inhibitor of metalloproteinases (TIMP-1) regulates extracellular type I collagen degradation by chondrocytes and endothelial cells. J Cell Sci 87:357-362

24. Herron GS, Banda MJ, Clark EJ, Gavrilovic J, Werb Z 1986 Secretion of metalloproteinases by stimulated capillary endothelial cells. II. Expression of collagenase and stromelysin activities is regulated by endogenous inhibitors. J Biol Chem 261:2814-2818

25. Herron GS, Werb Z, Dwyer K, Banda MJ 1986 Secretion of metalloproteinases by stimulated capillary endothelial cells. I. Production of procollagenase and prostromelysin exceeds expression of proteolytic activity. J Biol Chem 261:2810-2813

26. Murphy G, Reynolds JJ 1985 Current views of collagen degradation: progress towards understanding the resorption of connective tissues. Bioassays 2:5560

27. Welgus HG, Campbell EJ, Bar-Shavit Z, Senior RM, Teitelbaum SL 1985 Human alveolar macrophages produce a fibroblast-like collagenase and collagenase inhibitor. J Clin Invest 76:219-224

28. Clark SD, Kobayashi DK, Welgus HG 1987 Regulation of the expression of tissue inhibitor of metalloproteinases and collagenase by retinoids and glucocorticoids in human fibroblasts. J Clin Invest 80:1280-1288

29. Veness-Meehan KA, Cheng ER, Mercier CE, Blixt SL, Johnston CJ, Watkins RH, Horowitz S 1991 Cell-specific alterations in expression of hyperoxiainduced mRNAs of lung. Am J Respir Cell Mol Biol 5:516-521

30. Meredith KS, deLemos RA, Coalson JJ, King RJ, Gerstmann DR, Kumar $R$ Kuehl TJ, Winter DC, Taylor A, Clark RH, Null Jr DM 1989 Role of lung injury in the pathogenesis of hyaline membrane disease in premature baboons. J Appl Physiol 66:2150-2158

31. Edwards DR, Murphy G, Reynolds JJ, Whitman SE, Docherty AJP, Angel P, Heath JK 1987 Transforming growth factor beta modulates the expression of collagenase and metalloproteinase inhibitor. EMBO J 6:1899-1904

32. Minoo P, Lin A, King R, deLemos R 1991 Expression of TGF- $\alpha$ in fetal and premature baboon lung. Pediatr Res 29:325A(abstr)

33. Lagercrantz $H$, Bistoletti $P 1973$ Catecholamine release in the newborn infant at birth. Pediatr Res 111:889-893

34. Padbury JY, Agata Y, Ludlow J, Ikegami M, Baylen B, Humme H 1987 Effect of fetal adrenalectomy on catecholamine release and physiologic adaptation at birth in sheep. J Clin Invest 80:1096-1103 